\title{
Rehabilitation of Mutilated Teeth - A Systematic Review
}

\section{Mithra N Hegde ${ }^{1 *}$ and Ashwini KS ${ }^{2}$}

${ }^{1}$ Vice-Principal, Head of the Department, Department of Conservative Dentistry and Endodontics, A B Shetty Memorial Institute of Dental Sciences, Deralakatte, Mangalore, India

${ }^{2}$ Postgraduate Student, Department of Conservative Dentistry and Endodontics, A B Shetty Memorial Institute of Dental Sciences, Deralakatte, Mangalore, India

*Corresponding Author: Mithra N Hegde, Vice-Principal, Head of the Department, Department of Conservative Dentistry and Endodontics, A B Shetty Memorial Institute of Dental Sciences, Deralakatte, Mangalore, India.

Received: November 04, 2019; Published: November 29, 2019

DOI: 10.31080/ASDS.2019.03.0717

\begin{abstract}
Statement of Problem: Dentists are commonly encountering the management/treatment decision of mutilated individual teeth Aim: The aim of this systematic review was to analyse the materials and methods in the clinical scenario used for rehabilitation of individually mutilated teeth using post and core.

Materials and Methods: A PubMed search was carried out systematically to find randomized controlled clinical trials, case reports until December 2018 from January 2008, and issued in single language i.e English associated with rehabilitation of mutilated teeth. Evidence based tables were developed by assessing the quality, inclusion and exclusion criteria.

Results: A PubMed search identified 1646 articles. From 2008 to 2018, 696 articles were available. After assessing the titles, subtitles, synopsis, and outline of the articles revealed that 658 were inapplicable and 40 seems to be applicable. Out of 40 articles, four randomized controlled clinical trials, 34 case reports. As stated by the great extent of facts, Glass Fiber posts showed better clinical success in long term follow up (RCT). Fiber posts showed better clinical success than metal posts in strength (Case reports).

Conclusion: Fiber glass posts showed excellent survival rates in clinical trials, with identical presentation as that of cast-post-and cores. Metallic posts also showed excellent clinical survival, but the allied failures were mainly irreparable. Majority of the data was chiefly found on invitro studies and to a lesser degree on clinical trials. The deficiency of long term follow up of randomized controlled clinical trials was the predominant obstacle to arrive at a convincing judgement. However, there is lack of documented evidence on gold cast post and core which is the limitation of this article.
\end{abstract}

Keywords: Caries; Coronal Fracture; Mutilated Teeth; Randomized Controlled Clinical Trials

Introduction

\section{Background}

Mutilated tooth is that tooth which is grossly weakened and badly broken down tooth where the volume of left over tooth shape is less than the amount of tooth loss. Mutilation of teeth is due to long standing caries or recurrent caries, over-zealous preparation and traumatic fracture of the tooth. Partial or complete coronal destruction of teeth is caused by the spread of decay underneath an existing crown.

\section{Objective}

The main objective of Conservative Dentistry and Endodontics is to identify the disease involving the dental, pulpal and periarticular structures and to retain the natural teeth with maximal function and pleasing aesthetics. Thus, restoring the health of the tooth. A good Prosthetic reconstruction of badly mutilated tooth following endodontic therapy is equally important treatment procedure as principally believed. When a coronal portion of tooth structure has lost in a large extent, a post can be 
used. The principal purpose of Post is to aid in the retention for a core. It is a very challenging clinical scenario when there is need to rehabilitate severely destructed tooth predominantly to impart coronal filling. Rehabilitation of badly broken molar following successful endodontic therapy should be contributed by a sound coronal restoration. There are many techniques of restoring a badly broken molar tooth. It should ideally meet the necessary needs such as function and aesthetics [1].

This review highlights the role of dowel and core in the management of badly mutilated individual teeth.

\section{Materials and Methods}

The main evidence based research question of this review was which type of post is good in clinical scenario when it is used for rehabilitating individual mutilated teeth. A PubMed search was carried out systematically to find randomized controlled clinical trials, case reports until December 2018 from January 2008 and issued in single language i.e English associated with rehabilitation of mutilated teeth. STROBE's criteria was considered for analysing the studies [2]. Search keywords developed to find the articles were post and core used in Endodontics, rehabilitation of grossly decayed teeth, rehabilitation of individual mutilated tooth using post and core, rehabilitation of complete coronal destruction of teeth using post and core, treatment of grossly decayed teeth, management of grossly decayed teeth, treatment of compromised teeth.

Inclusion and exclusion criteria

Inclusion criteria

Mutilated teeth by caries, rehabilitation only for single or $2 / 3$ teeth, trauma (where dentin replacement is required), In vivo Randomized controlled clinical trials evidence based results analysis studies conducted in humans, related to the question, Quantitative results provided, Published in English language.

\section{Exclusion criteria}

Full mouth rehabilitation including Worn out dentition (loss of vertical dimension), Congenital abnormalities, Developmental defects (Amelogenesis imperfecta, Dentinogenetic imperfecta (where full mouth rehabilitation is required), Fluorosis.

\section{Results}

A PubMed search identified 1646 articles. From 2008 to 2018, 696 articles were available. After assessing the titles, subtitles, synopsis, and outline of the articles revealed that 658 were inapplicable and 40 seems to be applicable. Out of 40 articles, four randomized controlled clinical trials, 34 case reports.

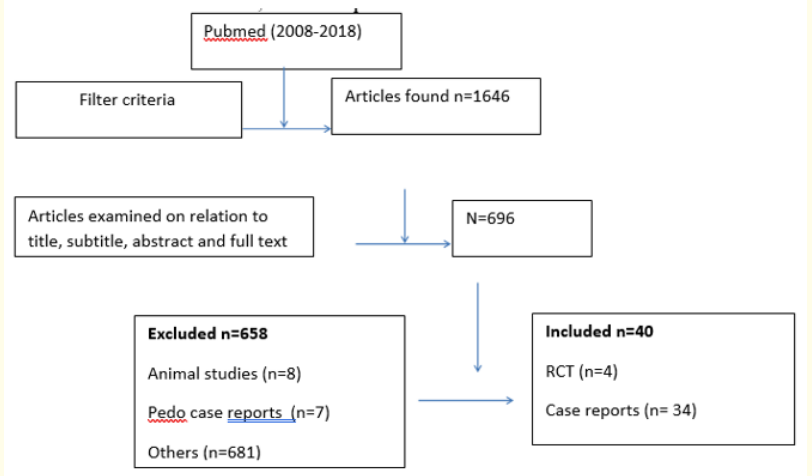

Figure 1

\begin{tabular}{|c|c|c|c|c|c|c|}
\hline Study & Materials and Methods & $\begin{array}{c}\text { Control } \\
\text { Group }\end{array}$ & $\begin{array}{c}\text { Experimental } \\
\text { Group }\end{array}$ & $\begin{array}{l}\text { Follow-up } \\
\text { Period }\end{array}$ & Results & Risk of Bias \\
\hline $\begin{array}{l}\text { Gbadebo OS, } \\
\text { Ajayi DM, } \\
\text { Oyekunle 00, } \\
\text { Shaba PO } \\
2014[3]\end{array}$ & $\begin{array}{l}40 \text { ETT requiring post } \\
\text { retained restorations ran- } \\
\text { domly divided into two } \\
\text { groups restored using a glass } \\
\text { fiber-reinforced post (FRP) } \\
\text { and stainless steel parapost } \\
\text { (PP), each in combination with } \\
\text { composite core buildups. } \\
\text { The samples were examined } \\
\text { radiographically and clinically. } \\
\text { Categorical values- Fisher's } \\
\text { exact test. } \\
\text { descriptive statistical analysis- } \\
\text { log-rank test. }\end{array}$ & $\begin{array}{c}\text { Metallic } \\
\text { post }\end{array}$ & Glass-fiber post & $\begin{array}{l}1 \text { and six } \\
\text { months }\end{array}$ & $\begin{array}{c}\text { Glass FRPs } \\
\text { performed } \\
\text { better than } \\
\text { the metallic } \\
\text { post }\end{array}$ & $\begin{array}{l}\text { Marginal defect was } \\
\text { found in both metal- } \\
\text { lic and glass-fiber } \\
\text { post(potential failure } \\
\text { of the restoration). } \\
\text { Although this } \\
\text { Was not found to be } \\
\text { statistically significant } \\
\text { based on short-term } \\
\text { clinical performance. } \\
\text { Low risk of bias }\end{array}$ \\
\hline
\end{tabular}




\begin{tabular}{|c|c|c|c|c|c|c|}
\hline $\begin{array}{l}\text { Sterzenbach } \\
\text { G, Franke A, } \\
\text { Naumann M } \\
2012[4]\end{array}$ & $\begin{array}{l}\text { Ninety-one subjects in need of } \\
\text { postendodontic restorations } \\
\text { received tapered titanium } \\
\text { post or a tapered glass fiber- } \\
\text { reinforced epoxy resin posts } \\
\text { - where teeth with two or less } \\
\text { remaining cavity walls. The } \\
\text { test used was log rank test }\end{array}$ & $\begin{array}{l}\text { Titanium } \\
\text { posts }\end{array}$ & $\begin{array}{l}\text { Prefabricated } \\
\text { glass fiber- } \\
\text { reinforced epoxy } \\
\text { resin posts }\end{array}$ & $\begin{array}{l}\text { Seven } \\
\text { years }\end{array}$ & $\begin{array}{l}\text { No statisti- } \\
\text { cal difference } \\
\text { found }\end{array}$ & $\begin{array}{c}\text { Failures were mainly } \\
\text { because of incomplete } \\
\text { ferrule effect. Lack } \\
\text { of prior sample size } \\
\text { determination. } \\
\text { High risk of bias }\end{array}$ \\
\hline $\begin{array}{l}\text { Bitter K, } \\
\text { Noetzel J, } \\
\text { Stamm 0, } \\
\text { Vaudt J, Mey- } \\
\text { er-Lueckel } \\
\text { H, Neumann } \\
\text { K., et al. } 2009 \\
\text { [5] }\end{array}$ & $\begin{array}{l}\text { Ninety patients providing } 120 \\
\text { teeth were selected. Three } \\
\text { groups ( } \mathrm{n}=40 \text { ) were defined } \\
\text { based on the amount of } \\
\text { Left out crown portion of } \\
\text { dentin: the groups were one } \\
\text { wall group, one coronal wall, } \\
\text { no wall group, no wall which } \\
\text { was exceeding } 2 \text { mm above the } \\
\text { gingival level } \\
\text { and randomized in each } \\
\text { group. Intervention in } 2 \\
\text { groups (n=20) including sub- } \\
\text { groups no post and subgroups } \\
\text { posts }\end{array}$ & No post & Fiber post & 32 months & $\begin{array}{l}\text { Teeth without } \\
\text { post reten- } \\
\text { tion revealed } \\
\text { a significantly } \\
\text { higher failure } \\
\text { rate } \\
\text { (31\%) com- } \\
\text { pared with } \\
\text { teeth restored } \\
\text { with post } \\
\text { retention } \\
(7 \%)\end{array}$ & $\begin{array}{c}\text { Lack of } \\
\text { completely } \\
\text { standardized } \\
\text { conditions with } \\
\text { type of teeth i.e } \\
\text { anterior/posterior. } \\
\text { High risk of bias }\end{array}$ \\
\hline $\begin{array}{l}\text { Karteva EG, } \\
\text { Manchorova } \\
\text { NA, Vladi- } \\
\text { mirov SB, } \\
\text { Keskinova } \\
\text { DA } 2018 \text { [6] }\end{array}$ & $\begin{array}{l}\text { Twenty-two patients who } \\
\text { received endodontic therapy } \\
\text { on premolars with a loss of } \\
\text { one or two proximal walls. } \\
\text { As stated by the restoration } \\
\text { methods, premolars were } \\
\text { allocated into groups: Metal } \\
\text { post group,fiber-post group, } \\
\text { and no post group. For the no } \\
\text { post group, a dentinal core of } \\
\text { fiber-reinforced composite } \\
\text { was used. The McNemar test, } \\
\text { marginal homogeneity test } \\
\text { and Kruskal-Wallis test were } \\
\text { used in the statistical analysis. }\end{array}$ & $\begin{array}{l}\text { Metal } \\
\text { post, } \\
\text { Fiber } \\
\text { post }\end{array}$ & $\begin{array}{l}\text { No post with } \\
\text { core of fiber- } \\
\text { reinforced com- } \\
\text { posite }\end{array}$ & $\begin{array}{l}6 \text { to } 12 \\
\text { months }\end{array}$ & $\begin{array}{l}\text { There were } \\
\text { no failures of } \\
\text { the different } \\
\text { posts used, } \\
\text { but there was } \\
\text { a progressive } \\
\text { deterioration } \\
\text { of the compos- } \\
\text { ite restora- } \\
\text { tions }\end{array}$ & $\begin{array}{l}\text { There was no proper } \\
\text { experimental and con- } \\
\text { trol group. } \\
\text { High risk of bias }\end{array}$ \\
\hline
\end{tabular}

Table 1

Analysis of the results of case reports (posts used for grossly decayed tooth)

\begin{tabular}{|l|c|c|c|c|c|}
\hline Study & $\begin{array}{c}\text { Type of tooth } \\
\text { destruction }\end{array}$ & Post & $\begin{array}{c}\text { Follow up } \\
\text { period }\end{array}$ & Results & Risk of bias \\
\hline $\begin{array}{l}\text { Abuabara A, Costa RG, } \\
\text { Morais EC, Furuse AY, } \\
\text { Gonzaga CC, Filho FB } \\
2013 \text { [5] }\end{array}$ & $\begin{array}{c}\text { Root perforation } \\
\text { and severe inter- } \\
\text { nal resorption of } \\
\text { maxillary central } \\
\text { incisor }\end{array}$ & $\begin{array}{c}\text { Glass fiber-rein- } \\
\text { forced post }\end{array}$ & 30 months & Clinically-Good & High risk of bias \\
\hline $\begin{array}{l}\text { Kumar S, Rao A, Sheila } \\
\text { K 2013 [6] }\end{array}$ & $\begin{array}{c}\text { Gross destruc- } \\
\text { tion of the crown } \\
\text { of the maxillary } \\
\text { central incisor } \\
\text { with periapical } \\
\text { lesion }\end{array}$ & $\begin{array}{c}\text { Anatomically-Not } \\
\text { post }\end{array}$ & Six months & Clinically-Good & Low risk of bias \\
\hline $\begin{array}{l}\text { Abuabara A, Costa RG, } \\
\text { Morais EC, Furuse AY, } \\
\text { Gonzaga CC, Filho FB } \\
\text { 2013 [7] }\end{array}$ & $\begin{array}{c}\text { Root perforation } \\
\text { and severe inter- } \\
\text { nal resorption of } \\
\text { maxillary central } \\
\text { incisor }\end{array}$ & 30 months & - & Clinically - Good & High risk of bias \\
\hline
\end{tabular}


Analysis of the results of case reports (posts used for fractured tooth)

Analysis of the results of case reports (posts used for fractured fragment reattachment)

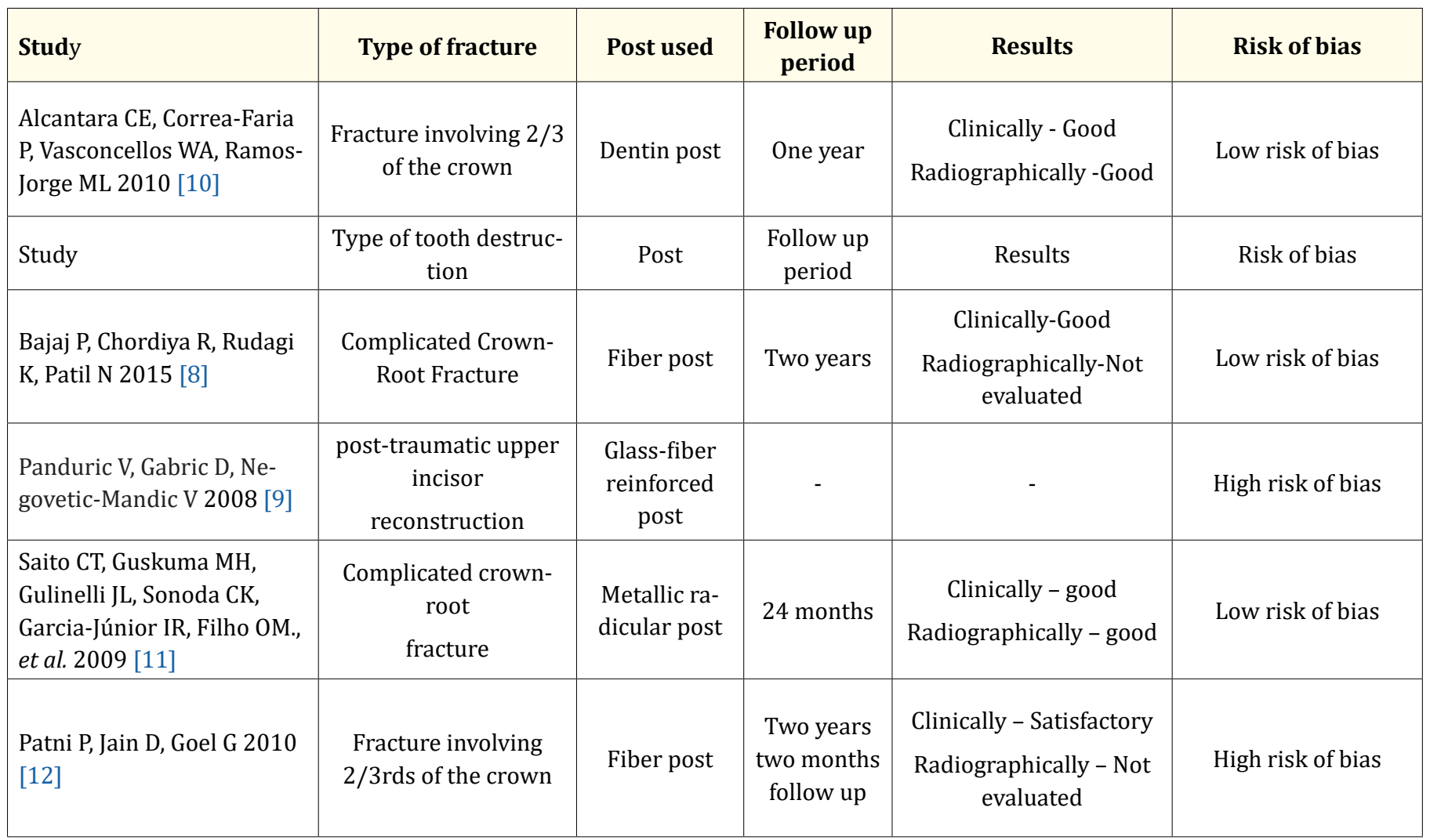

Table 3

\section{Analysis of the results of reviewers}

Fiber posts demonstrated good clinical and radiographic results similar to the performance of Cast-post and cores. However, Metallic posts associated failures led to irreversible damage to the periodontium.

\section{Discussion}

The traditional methods of rehabilitation of mutilated teeth using Cast post with alloys of Gold, Cobalt chromium and Nickelchromium have been seen to be clinically and radiographically successful. However, Metallic posts associated failures leads to irreversible damage which leads to the advent of Prefabricated posts such as (Metallic) Titanium, Stainless steel, Brass, etc. Recently Non-metallic carbon fiber posts were also used, but the conventional cast post fabrication is time consuming, poor esthetics, poor adhesion to composite resins, lack of radiopacity. Custom cast posts are more prone for root fracture, poor esthetics. Glass fiber post which is esthetically acceptable, elastic modulus same as that of dentin, fracture resistance is high. These are the advantages of glass-fiber post. However, there was no literature giving us a complete systematic review on clinical studies. So, the need for an assessment of the clinical studies of fiber post system. Hence, this study was conducted to analyse the materials and methods in the clinical scenario used for rehabilitation of individual mutilated teeth using post and core.

A PubMed search identified 1646 articles. From 2008 to 2018, 696 articles were available. After assessing the titles, subtitles, synopsis, and outline of the articles revealed that 658 were 
inapplicable and 40 seems to be applicable. Out of 40 articles, four randomized controlled clinical trials, 34 case reports.

Theodosopoulou., et al. carried out a systematic review in 2009 to evaluate which type of post and core system is the most wellto-do when it is used in clinical scenario to re-establish root canal treated tooth. The review recognized Six Randomized controlled trials, two Case control trials and two CSs and they arrived at an opinion that carbon fiber in resin matrix posts are significantly more desirable than cast posts (precious alloy) (RCT). Glass fiber posts are significantly more desirable than metal screw posts (RCT) and comparatively better than quartz fiber posts (CCT). Carbon fiber posts are inferior than metal posts (RCT). Prefabricated metal posts are moderately more desirable than cast posts (RCT) [13].

\section{Randomized controlled clinical trials results analysis}

The results of determined four Randomized controlled trials were showed that none of the trials were applicable with the STROBE's list of items to describe RCT's of post and core. They were lacking in random sample of a population, allotment and its execution. Also, these trials did not describe the blinding method and adverse effects.

Out of four RCT's, all the short term results were good. However, one study (Guido Sterzenbach., et al. 2012) had a long-term follow-up of 7 years which showed that failure was because of the incomplete ferrule.

\section{Analysis of the results of Case reports}

Out of 34 case reports, 21 studies showed good results using fiber posts. However other studies also showed good results, but varied in the follow up period i.e from six months to two years.

\section{Conclusion}

Fiber glass posts showed excellent survival rates in clinical trials, with identical presentation as that of cast-post-and cores. Metallic posts also showed excellent clinical survival, but the allied failures were mainly irreparable. Majority of the data was chiefly found on invitro studies and to a lesser degree on clinical trials. The deficiency of long term follow up of randomized controlled clinical trials was the predominant obstacle to arrive at a convincing judgement. However, there is lack of documented evidence on gold cast post and core which is the limitation of this article.

\section{Bibliography}

1. Chaudhary S., et al. "Restorative management of grossly mutilated molar teeth using endocrown: A novel concept". Journal of Restorative Dentistry 4.3 (2016): 97.

2. Von Elm E., et al. "The Strengthening the Reporting of Observational Studies in Epidemiology (STROBE) statement: guidelines for reporting observational studies". Annals of internal medicine 147.8 (2007): 573-577.

3. Gbadebo OS., et al. "Randomized clinical study comparing metallic and glass fiber post in restoration of endodontically treated teeth". Indian Journal of Dental Research 25.1 (2014): 58.

4. Sterzenbach G., et al. "Rigid versus flexible dentine-like endodontic posts-clinical testing of a biomechanical concept: seven-year results of a randomized controlled clinical pilot trial on endodontically treated abutment teeth with severe hard tissue loss"'”. Journal of Endodontics 38.12 (2012): 1557-63.

5. Abuabara A., et al. "Prosthetic Rehabilitation and Management of an MTA-Treated Maxillary Central Incisor with Root Perforation and Severe Internal Resorption". Journal of Prosthodontics 22.5 (2013): 413-418.

6. Kumar S., et al. "Multidisciplinary Approach in Management of Fractured Central Incisor through Composite Plug Stabilization-A Case Report". Journal of international oral health 5.1 (2013): 79.

7. Abuabara A., et al. "Prosthetic Rehabilitation and Management of an MTA-Treated Maxillary Central Incisor with Root Perforation and Severe Internal Resorption". Journal of Prosthodontics 22.5 (2013): 413-8.

8. Bajaj P., et al. "Multidisciplinary approach to the management of complicated crown-root fracture: a case report". Journal of international oral health 7.4 (2015): 88.

9. Panduric V., et al. "Immediate post-traumatic upper incisor reconstruction using composite resin materials". Dental Traumatology 24.1 (2008): 108-11.

10. Alcântara CE., et al. "Combined technique with dentin post reinforcement and original fragment reattachment for the esthetic recovery of a fractured anterior tooth: a case report". Dental Traumatology 26.5 (2010): 447-450. 
11. Saito CT., et al. "Management of a complicated crown-root fracture using adhesive fragment reattachment and orthodontic extrusion". Dental Traumatology 25.5 (2009): 541-4.

12. Patni P., et al. "A holistic approach to management of fractured teeth fragments: a case report". Oral Surgery, Oral Medicine, Oral Pathology, and Oral Radiology 109.5 (2010): e70-4.

13. Theodosopoulou JN and Chochlidakis KM. "A systematic review of dowel (post) and core materials and systems". Journal of Prosthodontics: Implant, Esthetic and Reconstructive Dentistry 18.6 (2009): 464-72.

Volume 3 Issue 12 December 2019

(C) All rights are reserved by Mithra N Hegde and Ashwini

KS. 